\title{
Releases and first recovery of Lathrolestes ensator (Hymenoptera: Ichneumonidae) in North America, a parasitoid of Hoplocampa testudinea (Hymenoptera: Tenthredinidae)
}

\author{
C Vincent, ${ }^{1}$ B Rancourt \\ Horticultural Research and Development Center, Agriculture and Agri-Food Canada, \\ 430 Gouin Boulevard, Saint-Jean-sur-Richelieu, Quebec, Canada J3B 3E6 \\ M Sarazin \\ ECORC, Central Experimental Farm, Agriculture and Agri-Food Canada, \\ 960 Carling Avenue, Ottawa, Ontario, Canada K1A 0C6
}

\section{U KuhImann}

CABI Bioscience Centre, Rue des Grillons 1, CH-2800 Delémont, Switzerland

The Canadian Entomologist 133: 147 - 149 (2001)

The European apple sawfly, Hoplocampa testudinea (Klug), is a pest of apple, Malus pumila Bork. (Rosaceae), in orchards. Introduced from Europe onto Long Island, New York, in 1939, it gradually invaded the New England states (Pyenson 1943). Downes and Andison (1942) also reported the apple sawfly on Vancouver Island in 1940. In 1979, H. testudinea was discovered for the first time in southern Quebec (Paradis 1980), after which it spread throughout the apple-growing areas of this province (Vincent and Mailloux 1988). There are no published records on any natural enemies of $H$. testudinea in North America.

Lathrolestes ensator Brauns (Hymenoptera: Ichneumonidae) is a solitary larval endoparasitoid known to attack only the European apple sawfly (Cross et al. 1999). It has been found in Poland (Jaworska 1987), the Netherlands (Zijp and Blommers 1993), Germany (Babendreier 1998), Switzerland (Babendreier 1998), and Italy (U Kuhlmann, unpublished data). Lathrolestes ensator is univoltine and is well-synchronized with its host. Only late first and second instar larvae can be parasitized successfully, even when there is a preponderance of third instars available (Babendreier 1996, 1998). A classical biological control program was initiated to introduce $L$. ensator to Canada by Agriculture and Agri-Food Canada in collaboration with CABI Bioscience Centre (formerly International Institute of Biological Control).

To collect $L$. ensator, apples damaged by $H$. testudinea were collected in Switzerland, Germany, and The Netherlands and transferred to the CABI Bioscience Centre laboratory in Delémont, Switzerland, where they were placed on wire screens over plastic trays to allow for emergence of $H$. testudinea larvae from the fruit and subsequent evaluation of parasitism. All larvae collected were examined individually for parasitism by $L$. ensator using a dissecting microscope. The parasitized host larvae (typically showing a dark spot inside) were placed onto soil into which they burrowed and formed cocoons. These cocoons were overwintered in a subterranean insectary. Prior to shipment to Canada, they were stored in darkness at $5^{\circ} \mathrm{C}$ to delay development and to allow for optimal host-parasitoid synchronization for release in Canada. In spring each year (1995-1999), cocoons were flown to the Agriculture and Agri-Food Canada National Quarantine facility in Ottawa. In May, a few weeks before the bloom stage of 'MacIntosh'

${ }^{1}$ Author to whom all correspondence should be addressed (E-mail: vincentch@em.agr.ca). 
Table 1. Releases of Lathrolestes ensator adults in Frelighsburgh, Quebec, 1995-1999.

\begin{tabular}{|c|c|c|c|c|c|}
\hline \multirow[b]{2}{*}{ Release date } & \multirow[b]{2}{*}{ Apple tree phenological stage } & \multirow[b]{2}{*}{ Country of origin* } & \multicolumn{3}{|c|}{$\begin{array}{c}\text { No. of Lathrolestes ensator } \\
\text { released }\end{array}$} \\
\hline & & & Males & Females & Total/year \\
\hline 1 June 1995 & Petal fall & $\mathrm{CH}$ & 64 & 74 & 138 \\
\hline 30 May 1996 & Petal fall & $\mathrm{CH}$ & 9 & 3 & \\
\hline 4 June 1996 & Petal fall & $\mathrm{CH}$ & 10 & 8 & 30 \\
\hline 5 June 1997 & Bloom & $\mathrm{CH}$ & 12 & 7 & 19 \\
\hline 20 May 1998 & Fruit set & $\mathrm{CH}, \mathrm{GER}, \mathrm{NL}$ & 27 & 126 & \\
\hline 22 May 1998 & Fruit set & CH, GER, NL & 18 & 10 & \\
\hline 26 May 1998 & Fruit set & $\mathrm{CH}, \mathrm{GER}, \mathrm{NL}$ & 22 & 82 & \\
\hline 29 May 1998 & Fruit $>1 \mathrm{~cm}$ & $\mathrm{CH}, \mathrm{GER}, \mathrm{NL}$ & 18 & 23 & 326 \\
\hline 21 May 1999 & Full bloom & $\mathrm{CH}$ & 18 & 52 & \\
\hline 26 May 1999 & Full bloom & $\mathrm{CH}$ & 14 & 7 & 91 \\
\hline Total & & & 212 & 392 & 604 \\
\hline
\end{tabular}

* CH, Switzerland; GER, Germany; NL, The Netherlands.

apple trees at the release site in Frelighsburgh $\left(45^{\circ} 03^{\prime} \mathrm{N}, 75^{\circ} 50^{\prime} \mathrm{W}\right)$, Quebec, the cocoons were stored at $16^{\circ} \mathrm{C}$ for a few days and at $18^{\circ} \mathrm{C}$ to allow emergence of the adult parasitoids in the quarantine facility. Emergence of $L$. ensator adults started in May and lasted for several days under quarantine laboratory conditions at $18^{\circ} \mathrm{C}$; protandry was observed. All male $L$. ensator emerged in the first $5 \mathrm{~d}$. Females began to emerge on the fourth day. Upon emergence, adults were kept in groups and allowed to mate. They were shipped by ground to the Horticultural Research and Development Center at Saint-Jeansur-Richelieu, Quebec.

Lathrolestes ensator adults were released for 5 consecutive years in an insecticidefree apple orchard located on the experimental farm of Agriculture and Agri-Food Canada at Frelighsburgh, Quebec (Table 1). This 0.66-ha orchard, composed chiefly of 12year-old 'MacIntosh' trees, has historically harbored high populations of $H$. testudinea (Vincent and Mailloux 1988). To measure the importance of sawfly populations, an assessment of primary (sensu Miles 1932, i.e., fruit showing ribbon scars on the epidermis) damage to the fruit was done at harvest each year. There was $2.6,1.2,1.0,1.4,1.8$, and $7.2 \%$ ( $n=500$ fruit) of fruit showing primary damage at harvest in 1993, 1994, 1995, 1996, 1997, and 1998, respectively.

To verify if $L$. ensator could successfully overwinter, fruitlets showing H. testudinea secondary (sensu Miles 1932, i.e., fruitlets pierced with circular holes showing frass at the entry point) damage were collected on 3 and 11 June 1998. Six plots randomly positioned within the orchard were prepared by digging $60 \times 90 \times$ $20 \mathrm{~cm}$ (length $\times$ width $\times$ depth) of soil underneath apple trees. A geotextile membrane was installed in the bottom and filled with soil that had been sieved ( $6 \mathrm{~mm}$ mesh size). Six hundred fruit (about $1.5 \mathrm{~cm}$ in diameter) showing secondary damage were placed on the sieved soil of each plot. They were covered with a screen ( $2 \mathrm{~mm}$ mesh size) to allow them to overwinter in the orchard. Dissection of 300 fruit from the same lot revealed that each fruit contained one larvae.

On 4 May 1999, the soil of each of the six plots was sieved ( $3 \mathrm{~mm}$ mesh size) and $474,363,384,400,72$, and 421 sawfly cocoons were found in these plots. The cocoons were transferred at $20^{\circ} \mathrm{C}$ in an incubator. A total of 1401 sawfly adults emerged between 11 May and 4 June 1999. Two female adult $L$. ensator emerged, demonstrating the first recovery of this parasitoid in North America. These two females were released on 1 and 8 June 1999 in the Frelighsburgh orchard (i.e., fruit about $1 \mathrm{~cm}$ in diameter). 
Three other specimens were deposited as vouchers in the National Insect collection in Ottawa. Their identification was confirmed by Andy Bennett, Royal Ontario Museum, Toronto, Ontario.

We thank Robert Trottier (formerly Research Coordinator, Pest Management, Agriculture and Agri-Food Canada, Ottawa) and Klaus Carl (formerly of the International Institute of Biological Control, Delémont, Switzerland) for facilitating this international cooperative project through the Agriculture and Agri-Food Canada - CABI Partnership Program, Isabelle Pronier (Université Picardie Jules Verne, Amiens, France) for technical work and Dirk D Babendreier (FAL, Zürich-Reckenholz, Switzerland) for his scientific contributions to improve the apple sawfly project in Europe.

Babendreier D. 1996. Studies on two ichneumonid parasitoids as potential biological control agents of the European apple sawfly, Hoplocampa testudinea Klug (Hymenoptera: Tenthredinidae). IOBC/WPRS Bulletin 19: 236-40

1998. Oekologie der Parasitoiden Lathrolestes ensator und Aptesis nigrocincta (Hym.: Ichneumonidae) sowie deren Einfluss auf Populationen ihres gemeinsamen Wirtes, der Apfelsägewespe, Hoplocampa testudinea (Hym.: Tenthredinidae). PhD thesis, University of Kiel, Kiel, Germany

Cross JV, Solomon, MG, Blommers L, Babendreier D, Easterbrook MA, Jay CN, Jenser G, Jolly RL, Kuhlmann U, Lilley R, Olivella E, Töpfer S, Vidal S. 1999. Biocontrol of pests of apples and pears in Northern and Central Europe: 2. Parasitoids. Biocontrol Science and Technology 9: 277-314

Downes W, Andison H. 1942. The apple sawfly Hoplocampa testudinea Klug on Vancouver Island, British Columbia. Proceedings of the Entomological Society of British Columbia 39: 13-6

Jaworska M. 1987. Obserwacje nad Lathrolestes marginatus (Thompson), pasozytem owocnicy jablkowejHoplocampa testudinea (Klug) (Hymenoptera, Tenthredinidae). [Observations on Lathrolestes marginatus (Thompson), a parasite of apple sawfly, Hoplocampa testudinea (Klug) (Hymenoptera, Tenthredinidae)]. (In Polish.) Polskie Pismo Entomologiczne 57: 553-67

Miles HW. 1932. On the biology of the apple sawfly, Hoplocampa testudinea (Klug). Annals of Applied Biology 19: 420-31

Paradis RO. 1980. L'hoplocampe des pommes, Hoplocampa testudinea (Klug) (Hymenoptera, Tenthredinidae) au Québec. Phytoprotection 61: 26-9

Pyenson L. 1943. A destructive apple sawfly new to North America, Journal of Economic Entomology 36: 218-21

Vincent C, Mailloux M. 1988. Distribution et importance de l'hoplocampe des pommes au Québec de 1981 à 1986 (Hymenoptera: Tenthredinidae). Annales de la Société Entomologique de France 24: 39-46

Zijp JP, Blommers L. 1993. Lathrolestes ensator, a parasitoid of the apple sawfly. Proceedings of Experimental \& Applied Entomology 4: 237-42

(Received: 31 July 2000; accepted: 28 September 2000) 